\title{
Identifikasi Bakteri pada Rumput Laut Euchema spinosum yang terserang penyakit Ice-ice di Perairan Pantai Kutuh
}

\author{
Suprabadevi Ayumayasari Saraswati ${ }^{a}$, I Made Sena Darmasetiyawana ${ }^{a}$ \\ ${ }^{a}$ Program Studi Manajemen Sumberdaya Perairan, Fakultas Kelautan dan Perikanan, Universitas Udayana, Bukit Jimbaran, Bali 80361, Indonesia \\ * Penulis koresponden. Tel.: +62-81-239-3656-45 \\ Alamate-mail: suprabadevi@yahoo.com
}

Diterima (received) 15 Desember 2015; disetujui (accepted) 19 Februari 2016; tersedia secara online (available online) 22 Februari 2016

\begin{abstract}
The main causes of ice-ice disease that seaweed production will decline. Bacterial infections occur due to fluctuations in climate change resulted in a decrease in water quality resulting in the durability of seaweed. When seaweed stress will facilitate pathogen infection. Disease pathogens cause damage to internal organs. The spread of bacterial disease in seaweed is generally very fast and can lead to death, so that the loss caused by this disease is quite large. Ice-ice disease occurrence is seasonal and contagious, so the impact on the selling price low. The results showed that there are two types of pathogenic bacteria that can potentially cause disease in which bacteria Vibrio alginoliticus and Pseudomonas aeruginosa. Climate change affects the spatial distribution of micro seaweed bacterial pathogens.
\end{abstract}

Keywords: Eucheuma spinosum; ice-ice; bacterial pathogens

\begin{abstract}
Abstrak
Rumput laut yang lemah akan mudah terserang bakteri patogen penyebab utama penyakit ice-ice sehingga produksi rumput laut akan menurun. Infeksi bakteri terjadi karena fluktuasi perubahan iklim yang mengakibatkan penurunan kualitas air yang berakibat pada daya tahan rumput laut. Ketika rumput laut stres akan memudahkan infeksi patogen. Penyakit bakteri patogen menimbulkan kerusakan pada organ dalam. Penyebaran penyakit bakterial pada rumput laut umumnya sangat cepat dan dapat menimbulkan kematian, sehingga kerugian yang ditimbulkan akibat wabah penyakit ini cukup besar. Kejadian penyakit ice-ice bersifat musiman dan menular, sehingga berdampak pada harga jual yang rendah. Hasil penelitian menunjukan bahwa terdapat 2 jenis bakteri patogen yang berpotensial menyebabkan penyakit yaitu bakteri Vibrio alginoliticus dan Pseudomonas aeruginosa. Perubahan iklim mikro mempengaruhi sebaran spasial bakteri pathogen rumput laut.
\end{abstract}

Kata Kunci: Euchema spinosum; ice-ice; bakteri patogen

\section{Pendahuluan}

Rumput laut merupakan salah satu komoditi ekspor yang potensial untuk dikembangkan. Saat ini Indonesia masih merupakan salah satu negara eksportir penting di Asia karena rumput laut tumbuh dan tersebar hampir diseluruh perairan Indonesia. Rumput laut masih banyak diekspor dalam bentuk bahan mentah yaitu berupa rumput laut kering. Rumput laut yang ada di perairan Indonesia tidak semua bermanfaat bagi manusia. Rumput laut yang banyak dimanfaatkan adalah dari jenis ganggang merah dan ganggang cokelat karena mengandung agar-agar, keraginan, porpiran, dan furcelaran.

Namun permasalahan yang sering timbul pada usaha budidaya rumput laut yaitu adanya serangan penyakit iceice. Gejala penyakit ice-ice umumnya ditandai dengan pemutihan pada bagian pangkal thallus, tengah dan ujung thallus muda, yang diawali dengan perubahan warna thallus menjadi putih bening atau transparan (DKP, 2004).

Pengendalian penyakit ice-ice pada rumput laut di Indonesia belum tertangani dengan baik yang berakibat penurunan produksi rumput laut. Untuk menghindari hal tersebut, perlu diupayakan pencegahan dan pengobatan terhadap penyakit rumput laut secara hati-hati dan teliti agar tidak menimbulkan kerugian pada produksi rumput laut.

Hasil identifikasi pada thallus rumput laut didapatkan bakteri patogen penyebab penyakit ice-ice pada pengelolaan budidaya rumput laut di perairan pantai Kutuh. Berdasarkan permasalahan diatas, perlu adanya kajian lebih lanjut untuk mengetahui secara pasti jenis bakteri yang ditemukan pada rumput laut yang terserang penyakit ice-ice sebagai acuan pengendalian dan pengobatan selanjutnya.

\section{Metode Penelitian}

\subsection{Waktu dan Lokasi Pengambilan Sampel}

Sampel rumput laut Eucheuma spinosum diambil dari usaha budidaya rumput laut di perairan pantai Kutuh Kecamatan Denpasar Selatan, Kabupaten Badung. Masing-masing sampel diambil pada lokasi budidaya 
sebanyak 25 gr rumput laut. Untuk data parameter kualitas air diambil sampel air ditempat yang sama dengan pengambilan sampel rumput laut.

\subsection{Metode Penanganan Sampel}

Sampel rumput Eucheuma spinosum terdiri atas 2 sampel yaitu bagian ujung thallus yang, terserang penyakit ice-ice (masing-masing sampel sebanyak $25 \mathrm{~g}$ ) yang diambil dari lokasi pengambilan sampel. Bagian ujung thallus yang terserang penyakit ice-ice diberi tanda Rumput laut yang sakit (RLS) Sampel disimpan dalam cooling box yang telah diberi air es untuk dibawa ke Laboratorium Balai Karantina Ikan Pengendalian Mutu dan Keamanan Hasil Perikanan (BPKIPM) Denpasar. Selanjutnya sampel rumput laut yang terinfeksi bakteri akan dilakukan isolasi dan identifikasi bakteri.

Pengukuran iklim mikro dapat dilakukan langsung di lokasi pengambilan sampel dengan menggunakan alat Automatic Watersample dan Digital Instruments. Parameter yang diuji adalah $\mathrm{pH}$ air, DO (Dissolved Oxygen), suhu, salinitas.

\section{Hasil dan Pembahasan}

\subsection{Isolasi Bakteri}

Isolasi dilakukan untuk mengambil bakteri pada organ target dan menumbuhkan pada media Tryptic Soy Agar (TSA). Pemurnian bakteri dilakukan untuk mengambil koloni bakteri yang dominan dari hasil penumbuhan bakteri melalui proses isolasi dan kemudian diinkubasi pada suhu 28 - $30{ }^{\circ} \mathrm{C}$ selama 24 jam. Koloni bakteri yang tumbuh dipilih berdasarkan bentuk dan ukuran warna, diinokulasikan pada TSA untuk selanjutnya diidentifikasikan genusnya.

\subsection{Uji Presumtif}

Uji presumtif dilakukan untuk memudahkan dalam tahap identifikasi, dengan mengetahui genus dari bakteri yang ditumbuhkan pengujian yang dilakukan adalah uji gram, uji katalase dan uji oksidase untuk mengetahui apakah bakteri bersifat gram positif atau gram negative. Hasil pengujian sampel dapat dilihat pada Tabel 1.

Tabel 1.

Hasil Uji Presumtif

\begin{tabular}{|c|l|c|c|}
\hline \multirow{2}{*}{ No. } & \multicolumn{1}{|}{ Pengujian } & Kode Sampel & Kode Sampel \\
\cline { 3 - 4 } & & RLS 1 & RLS 2 \& 3 \\
\hline 1. & Uji Gram & + & + \\
\hline 2. & Uji Katalase & + & + \\
\hline 3. & Uji Oksidase & + & + \\
\hline \multicolumn{2}{|l}{} \\
\hline
\end{tabular}

\subsection{Uji Biokimia}

Uji biokimia dilakukan untuk mengetahui species bakteri dengan melihat kemampuannya tumbuh di masing-masing media. Pada uji biokimaia isolate diambil dengan jarum ose yang telah disterilkan dan diinokulasikan pada media semi solid (SIM Agar). Hasil pengujian sampel dapat dilihat pada Tabel 2 .

Tabel 2.

Hasil Uji Biokimia

\begin{tabular}{|c|c|c|c|c|}
\hline \multirow[t]{2}{*}{ No. } & \multirow[t]{2}{*}{ Pegujian } & $\begin{array}{c}\text { Kode } \\
\text { Sampel }\end{array}$ & $\begin{array}{c}\text { Kode } \\
\text { Sampel }\end{array}$ & $\begin{array}{c}\text { Kode } \\
\text { Sampel }\end{array}$ \\
\hline & & RLS 1 & RLS 2 & RLS III \\
\hline 1. & $\begin{array}{l}\text { Glukosa } \\
\text { Media/Gas }\end{array}$ & $+/+$ & $+/+$ & $+/-$ \\
\hline 2 & $\mathrm{OF}$ & $\mathrm{F}$ & $\mathrm{F}$ & $\mathrm{O}$ \\
\hline 3 & Citrate & - & - & + \\
\hline 4 & Nitrat & + & + & + \\
\hline 5 & Ornithin & - & - & - \\
\hline 6 & Lysin & + & + & - \\
\hline 7 & SIM Motility $/ \mathrm{H}_{2} \mathrm{~S}$ & $+/-$ & $+/-$ & $+/-$ \\
\hline 8. & SIM Indol & + & + & - \\
\hline 9. & Gelatin & + & + & - \\
\hline 10. & Urea & - & - & - \\
\hline 11. & MRVP uji MR & + & + & - \\
\hline 12. & MRVP Uji VP & + & + & - \\
\hline 13. & TSIA Miring & $\mathrm{A}$ & $\mathrm{A}$ & Alk \\
\hline 14. & TSIA Tegak & A & A & Alk \\
\hline 15. & TSIA Gas/ $\mathrm{H}_{2} \mathrm{~S}$ & $+/-$ & $+/-$ & $-/-$ \\
\hline 16. & Lactosa & - & - & - \\
\hline 17. & Sucrosa & + & + & - \\
\hline 18. & Arabinosa & - & - & - \\
\hline 19. & Sorbitol & - & - & - \\
\hline 20. & Inositol & - & - & - \\
\hline 21. & Dulcitol & - & - & - \\
\hline 22. & Manitol & + & + & + \\
\hline 23. & Trehalose & & & \\
\hline 24. & Rafinose & & & \\
\hline 25. & TCBS Koloni & $\mathrm{K}$ & $\mathrm{K}$ & \\
\hline 26. & TCBS Media & $\mathrm{K}$ & $\mathrm{K}$ & \\
\hline 27. & GSP Koloni & & & $\mathrm{M}$ \\
\hline 28 & $\begin{array}{l}\text { GSP Media } \\
\text { (selektif media) }\end{array}$ & & & M \\
\hline 29. & $\mathrm{NaCl} 4 \%$ & + & + & + \\
\hline 30. & $\mathrm{NaCl} 6 \%$ & - & - & - \\
\hline 31. & Haemolisa & $\mathrm{NH}$ & $\mathrm{NH}$ & $\mathrm{NH}$ \\
\hline 32. & $37^{\circ} \mathrm{C}$ & & & \\
\hline Kes & mpulan & \begin{tabular}{|l} 
Vibrio \\
alginolyticus
\end{tabular} & $\begin{array}{l}\text { Vibrio } \\
\text { alginolyticus }\end{array}$ & $\begin{array}{l}\text { Pseudomona } \\
\text { Aeruginosa }\end{array}$ \\
\hline
\end{tabular}

Sumber: Diolah dari primer

\subsection{Karakteristik Morfologi Bakteri}

Identifikasi bakteri Vibrio sp. pada rumput laut Euchema spinosum didahului dengan isolasi rumput laut Euchema spinosum yang terserang ice-ice pada media TCBS sebagai media selektif Vibrio sp. Hasil isolasi rumput laut Euchema spinosum yang terserang ice-ice pada media TCBS diperoleh hasil koloni bakteri Vibrio alginolyticus. ditandai dengan berubahnya media yang berwarna hijau menjadi kuning (Gambar 1 dan 2).

Hasil karakteristik bakteri Vibrio telah dilakukan uji lanjut biokimia. Pada uji indol Vibrio menunjukan hasil positif dan bersifat motil. Sedangkan pada uji fermentasi, sukrosa dan manitol bakteri Vibrio juga memberi hasil positif yaitu dapat melakukan fermentasi sukrosa dan manitol, namun pada uji laktosa didapat hasil negatif yaitu tidak dapat memfermentasikan laktosa dengan menggunakan media TSIA hasil yang muncul adalah bagian atas menunjukan warna merah yang berarti bersifat basa, dan bagian bawah berwarna kuning yang 
berarti bersifat asam, dan tidak terbentuk $\mathrm{H}_{2} \mathrm{~S}$. Uji lisin dekarboksilasi terhadap Vibrio juga menunjukkan hasil positif berupa warna ungu, uji $\mathrm{NaCl} 4 \%$ memberi hasil positif berupa kekeruhan yang tinggi ditemukan jenis bakteri Vibrio alginolyticus yang terdapat pada rumput laut Euchema spinosum yang terserang penyakit ice-ice. Bakteri vibrio bersifat aerob, tetapi ada pula yang bersifat anaerob fakultatif. Selain itu, vibrio juga bersifat motil karena pergerakannya dikendalikan oleh flagela polar, tergolong bakteri gram negatif (Choopun et al, 2002).

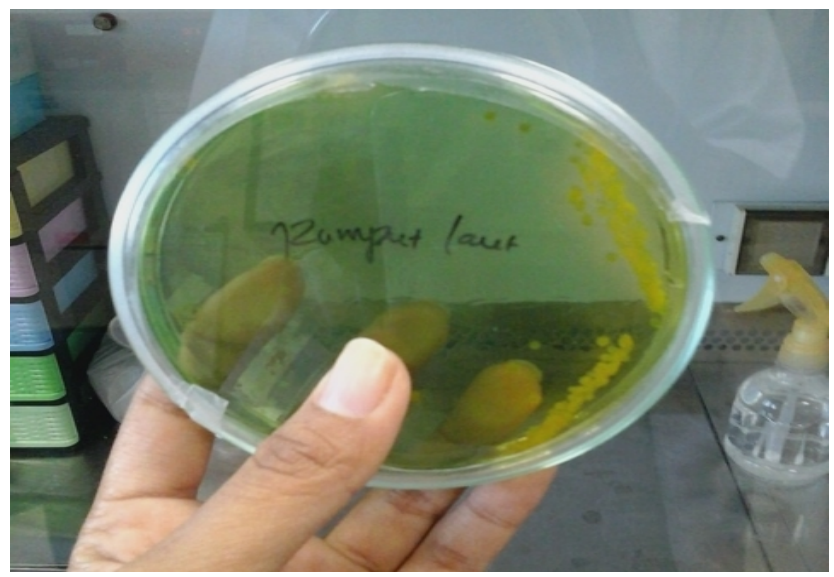

Gambar 1. Hasil Penumbuhan Bakteri Vibrio alginolyticus yang Diisolasi dari Rumput Laut Euchema spinosum pada Lokasi 1.

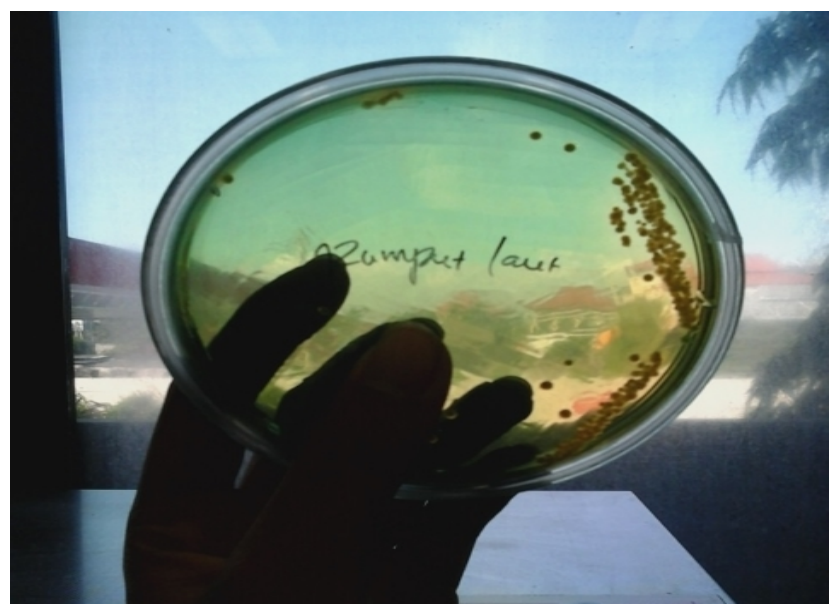

Gambar 2. Hasil Penumbuhan Bakteri Vibrio alginolyticus yang Diisolasi dari Rumput Laut Euchema spinosum pada Lokasi 2.

Hanna et al. (1992) menyatakan bahwa Vibrio alginolyticus. merupakan bakteri berbentuk basil (batang) dan bersifat motil (dapat bergerak), berhabitat alami di lingkungan akuatik dan umumnya berasosiasi dengan Bakteri dari spesies Vibrio secara langsung akan menimbulkan penyakit pathogen, yang dapat menyebabkan kematian biota laut dan secara tidak langsung bakteri yang terbawa biota laut seperti ikan dan rumput laut akan dikonsumsi oleh manusia, sehingga menyebabkan penyakit pada manusia.

Hasil karakteristik bakteri Pseudomonas aeruginosa telah dilakukan uji lanjut biokimia. Pada uji indol menunjukan hasil positif dan bersifat motil. Pada uji fermentasi sukrosa memberi hasil negatif, sedangkan pada uji manitol memberi hasil positif. Dengan menggunakan media GSP hasil yang muncul adalah bagian atas dan bawah yang menunjukan warna merah yang berarti bersifat basa, dan tidak terbentuk $\mathrm{H}_{2} \mathrm{~S}$. Uji lisin dekarboksilasi terhadap Pseudomonas juga menunjukkan hasil negatif berupa warna kuning, uji $\mathrm{NaCl} 4 \%$ memberi hasil positif berupa kekeruhan yang tinggi ditemukan jenis bakteri Pseudomonas aeruginosa yang terdapat pada rumput laut Euchema spinosum yang terserang penyakit ice-ice dapat dilihat pada (Gambar 3). Pseudomonas aeruginosa berbentuk batang bakteri ini terlihat sebagai bakteri tunggal, berpasangan, dan terkadang membentuk rantai yang pendek. Pseudomonas aeruginosa termasuk bakteri gram negatif. Bakteri ini bersifat aerob, katalase positif, oksidase positif, tidak mampu memfermentasi tetapi dapat mengoksidasi glukosa/karbohidrat lain, tidak berspora, tidak mempunyai selubung (sheat) dan mempunyai flagel monotrika (flagel tunggal pada kutub) sehingga selalu bergerak. Pseudomonas aeruginosa merupakan patogen utama bagi manusia. Bakteri ini kadang-kadang mengkoloni pada manusia dan menimbulkan infeksi apabila fungsi pertahanan inang abnormal.

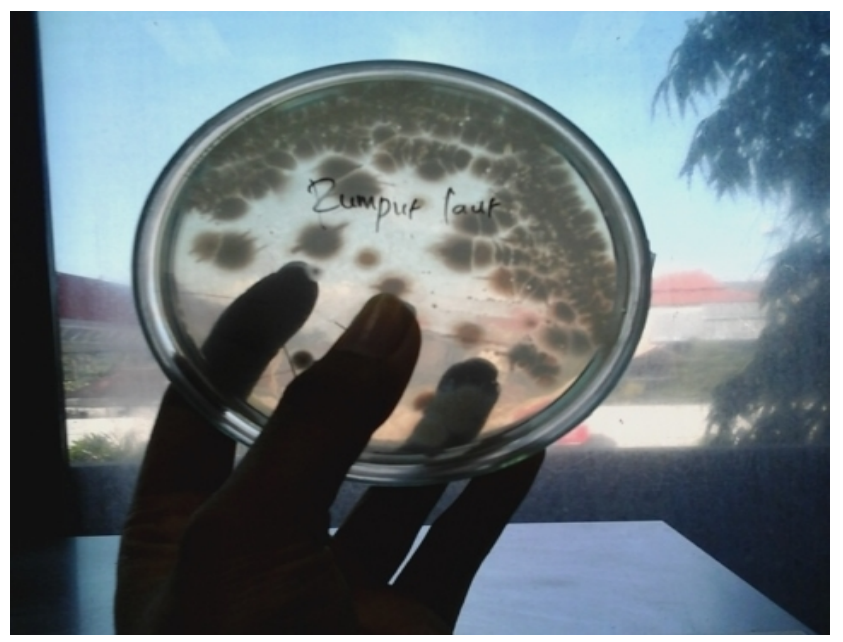

Gambar 3. Hasil Penumbuhan Bakteri Pseudomonas aeruginosa yang Diisolasi dari Rumput Laut Euchema spinosum pada Lokasi 3.

\subsection{Morfologi Rumput Laut yang Terkena Ice-Ice}

Gejala penyakit ice-ice umumnya ditandai dengan pemutihan pada bagian pangkal thallus, tengah dan ujung thallus muda, yang diawali dengan perubahan warna thallus menjadi putih bening atau transparan, serta menjadi pucat dan pada beberapa cabang menjadi membusuk (Largo et al. 1995). Thallus menjadi rapuh dan mudah putus, gejala yang diperlihatkan adalah pertumbuhan yang lambat. Ketika rumput laut mengalami stress akan memudahkan infeksi patogen. Pada keadaan stress, rumput laut akan membebaskan substansi organik yang menyebabkan thallus berlendir dan merangsang bakteri tumbuh melimpah. Pada umumnya penyebaran penyakit ice-ice terjadi secara vertikal oleh bibit thallus dan secara horizontal melalui perantaraan air (DKP, 
2004). Morfologi rumput laut yang terkena ice-ice dapat dilihat pada Gambar 4.
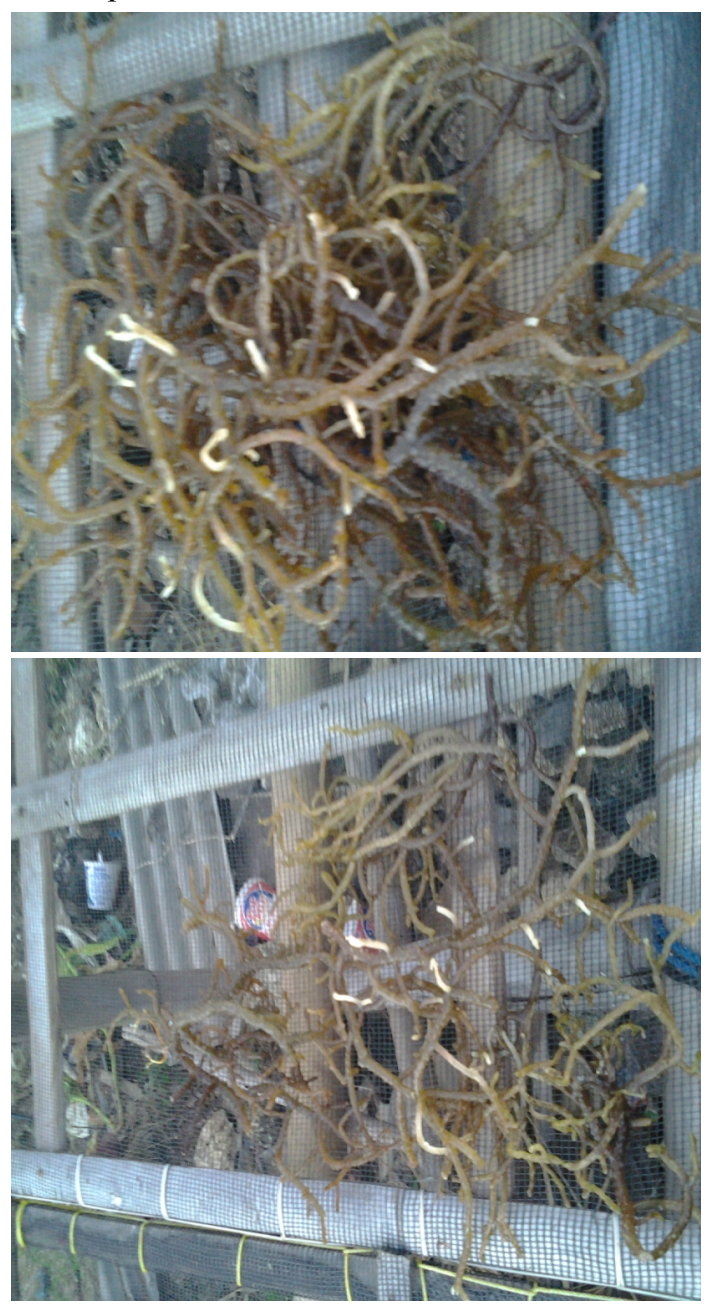

Gambar 4. Rumput Laut Eucheuma spinosum yang terkena iceice

Dari Hasil pengukuran suhu perairan pada setiap stasiun pengamatan diperlihatkan pada Tabel 4. Temperatur rata-rata di perairan adalah $28-29{ }^{\circ} \mathrm{C}$. Suhu perairan sangat penting untuk proses fotosintesis rumput laut. Salinitas rata-rata di perairan adalah 26-29 ppm yang dimana dekat dari daratan sehingga dipengaruhi oleh kegiatan dari darat Suhu air yang tinggi dan penurunan salinitas yang terjadi di perairan akibat air tawar yang masuk akan menyebabkan pertumbuhan rumput laut menjadi tidak normal. Di perairan pantai kisaran salinitas yang normal adalah 28-32 ppm (Winarno, 1996). Sedangkan pada lokasi budidaya rumput laut Eucheuma sp memiliki kisaran salinitas antara 26-33 ppm. Menurut Soenardjo (2003), lokasi budidaya diusahakan jauh dari sumber air tawar seperti dekat muara sungai karena dapat menurunkan salinitas air itu. Nilai $\mathrm{pH}$ mengalami peningkatan pada musim kemarau sebesar 8,12-8,13 dan kadar oksigen terlarut (DO) 6,5-6,7 ppm Pada kondisi pH tersebut terjadi peningkatan pertumbuhan bakteri. Effendi (2003) menjelaskan bahwa pertumbuhan bakteri akan lebih baik pada keadaan $\mathrm{pH}$ normal sampai relatif alkalin (basa).
Hasil pengukuran kekeruhan di lokasi penelitian berkisar antara 4,8-5,0 NTU. Kekeruhan adalah suatu ukuran biasan cahaya di dalam air yang disebabkan oleh adanya partikel koloid dan suspensi dari suatu polutan yang terkandung dalam air (Wetzel, 1983). Kekeruhan yang tinggi didapat di lokasi perairan dapat mengakibatkan penetrasi cahaya yang rendah. Kekeruhan dalam perairan untuk budidaya rumput laut adalah 0 gram/liter, hal ini sangat baik untuk tanaman melakukan fotosintesis karena dapat mempengaruhi pertumbuhan dan mutu tanaman (Soenardjo, 2003). Pertumbuhan Eucheuma spinosum adalah dasar perairan yang terdiri dari potonganpotongan karang mati dan bercampur dengan pasir karang, ditumbuhi oleh komunitas yang terdiri dari makro algae (Ditjenkan Budidaya, 2005).

\section{Simpulan}

1. Bakteri patogen yang ditemukan pada Rumput Laut di perairan Pantai Kutuh merupakan bakteri patogen yang berpotensial menyebabkan penyakit yaitu Vibrio sp dan Pseudomonas sp.

2. Parameter salinitas dan suhu yang meningkat akan berpengaruh terhadap pertumbuhan rumput laut. Salinitas rata-rata di perairan adalah 26-29 ppm yang dimana dekat dari daratan sehingga dipengaruhi oleh kegiatan dari darat Suhu air yang tinggi dan penurunan salinitas yang terjadi di perairan akibat air tawar yang masuk akan menyebabkan pertumbuhan rumput laut menjadi tidak normal.

3. Ketika rumput laut mengalami stress akan memudahkan infeksi patogen. Pada keadaan stress, rumput laut akan membebaskan substansi organik yang menyebabkan thallus berlendir dan merangsang bakteri tumbuh melimpah.

\section{Ucapan terimakasih}

Atas asung kerta wara nugraha Ida Sang Hyang Widhi Wasa, penelitian ini dapat terlaksana dengan baik. Penelitian ini dapat terlaksana atas dana dari Fakultas Kelautan dan Perikanan, Universitas Udaya. Penulis mengucapkan terimakasih kepada semua pihak yang telah membantu penelitian ini, mulai dari penyusunan proposal, pelaksanaan penelitian sampai penulisan laporan.

\section{Daftar Pustaka}

Choopun, N., Louis, V., Huq, A., \& Colwell, R. R. (2002). Simple procedure for rapid identification of Vibrio cholerae from the aquatic environment. Applied and Environmental Microbiology, 68(2): 995-998.

DKP. (2004). Profil Rumput Laut Indonesia. Jakarta-Indonesia: Direktorat Jendral Perikanan Budidaya.

Ditjenkan Budidaya. (2005). Profil Rumput Laut Indonesia. Jakarta-Indonesia: Departemen Kelautan dan Perikanan.

Effendi, H. (2003). Telaah Kualitas Air bagi Pengelolaan Sumberdaya dan Lingkungan Perairan. YogyakartaIndonesia: Penerbit Kanisius.

Hanna, P. J., Altmann, K., Chen, D., Smith, A., Cosic, S., Moon, P., \& Hammond, L. S. (1992). Development of monoclonal 
antibodies for the rapid identification of epizootic Vibrio species. Journal of Fish Diseases, 15(1): 63-69.

Largo, D. B., Fukami, K., \& Nishijima, T. (1995). Occasional pathogenic bacteria promoting ice-ice disease in the carrageenan-producing red algae Kappaphycus alvarezii and Eucheuma denticulatum (Solieriaceae, Gigartinales, Rhodophyta). Journal of Applied Phycology, 7(6): 545-554.
Sukardi, D. K. (2004). Metodologi Penelitian Pendidikan Jakarta-Indonesia: Percetakan Bumi Aksara.

Soenardjo, N. (2003). Membudidayakan Rumput Laut. Semarang-Indonesia: Balai Pustaka Semarang.

Winarno, F. G. (1996). Teknologi Pengolahan Rumput Laut. Jakarta-Indonesia: Pustaka Sinar Harapan.

Wetzel, R. G. (1983). Limnology. Second Edition. TorontoCanada: Saunders College Publishing.

(C) 2016 by the authors; licensee Udayana University, Indonesia. This article is an open access article distributed under the terms and conditions of the Creative Commons Attribution license (http://creativecommons.org/licenses/by/3.0/). 